\title{
Sustainable Development Goals through Energy cooperation in ASEAN
}

\author{
N. Agya Utama $^{1,2^{*}}$, Akbar Swandaru ${ }^{1}$,Hoy-Yen Chan, and Nadilah Shani ${ }^{1}$ \\ ${ }^{1}$ ASEAN Centre for Energy, 12950 Jakarta, Indonesia \\ ${ }^{2}$ Swiss German University, Tangerang, Banten, Indonesia
}

\begin{abstract}
The ASEAN primary energy demand to grow by an average of $3.4 \%$ per year from 627 to reach 1,450 million tons of oil equivalent by 2040 . In the alignment to accelerating the energy transition through the ASEAN, the region is aiming to reach $23 \%$ of RE in the total primary energy supply (TPES). With the five-year remaining, ASEAN has a lot opportunity to accelerate the effort. This research presents overview of the shaping of the renewables and low-carbon power utilisation which has been in the action plan to optimise effective and efficient power utilisation. It will be presented in the study report, the alignment of low-carbon society and renewable energy promotion in ASEAN has been in great progress considering its attempt to improve all power utilisation lineage.
\end{abstract}

\section{Introduction}

The 2030 Agenda for Sustainable Development, a shared blueprint for peace and prosperity was adopted by all United Nations Member States in 2015. One of the 17 Sustainable Development Goals (SDGs), the SDG7 is to "Ensure access to affordable, reliable, sustainable and modern energy for all". Therefore, not only the ASEAN member states shape their national energy policies to be aligned with the SDG7, but at the regional level, ASEAN is attaining this goal through the ASEAN Energy Cooperation policy framework. ASEAN Plan of Action for Energy Cooperation (APAEC) is a series of policy document that aims to enhance the multilateral energy cooperation and integration to attain the goals of the ASEAN Economic Community (AEC). At the present, the fourth APAEC 2016-2025 is formulated with a strategic theme, "Enhancing energy connectivity and market integration in ASEAN to achieve energy security, accessibility, affordability and sustainability for all" [1]. This 10-year policy framework is implemented in two phases, i.e Phase I from 2016 to 2020 and Phase II from 2021 to 2025. In addition, to ensure ASEAN energy cooperation is in-line with the global energy development, a sub-theme is endorsed for the APAEC Phase II 2021-2025, "Enhancing Energy Transition and Strengthening Energy Resilience through Greater Innovation and Cooperation". Furthermore, regional energy targets are set under the APAEC framework as such as to increase the component of renewable energy to $23 \%$ by 2025 in ASEAN energy mix and reduce energy intensity by $20 \%$ in 2020 and $30 \%$ in 2025 based on 2005 level.

\footnotetext{
* Corresponding author: utama@aseanenergy.org
} 
Apart from the SDG7, climate change mitigation from the energy sector is relevant to the SDG 13 on "Climate Action". In September 2019, ASEAN submitted a joint statement to the United Nations Climate Action Summit with key ASEAN targets for energy transition and transportation [2]. The submitted energy transition targets are the renewable energy and energy efficiency targets of the APAEC 2016-2025, whereas the transportation target is to reduce the average fuel consumption per $100 \mathrm{~km}$ of new light-duty vehicles sold in ASEAN by $26 \%$ between 2015 and 2025 . Therefore, not only the APAEC is a policy framework in attaining sustainable energy, but also a cornerstone of regional climate action in addressing climate change. The ASEAN energy cooperative efforts are thus crucial, and this was acknowledged in the Intended Nationally Determined Commitments (INDCs) of member states. For instance, Brunei acknowledged the importance of the regional energy cooperation network in knowledge-sharing and capacity-building [3]; while Lao PDR noted that the expansion of hydropower needs regional cooperation on power trading across neighbouring countries such as Cambodia, Vietnam, Thailand and Singapore [4].

The demand in primary energy in the region is expected to grow by an average of $3.4 \%$ per year from 627 to reach 1,450 million tons of oil equivalent in 2040, according to the ASEAN Center for Energy's (ACE's) 5th ASEAN Energy Outlook [5]. In ASEAN, coal accounts for around $15 \%(72 \mathrm{GW})$ of power generation in the region and is expected to double its capacity by 2040. Coal resource is abundant in ASEAN for many years to come, forecasted to be about 12-14 billion metric tons in 2035, which would be an important energy sources for ASEAN in ensuring energy affordability, security and resilience. In the other hand, with the increasing issue of climate change, there is a need for coal to adapt so it can play a role for energy transition in ASEAN. With a proper technology coal could play role on providing 'a competitive' energy supply therefore inline with the aim to achieve the SDG7.

\section{Progress and achievements of SDG7 and SDG13 in the Southeast Asia}

The United Nations Economic and Social Commission for Asia and the Pacific (UN ESCAP) recently published a progress report on the Asia and the Pacific SDG [6]. As shown in Figure 1, the achievements of SDG7 and SDG13 in Southeast Asia are relatively low compared to the other SDGs. The report found that only the indicator of access to electricity is on-track, while the renewable energy (RE) share is declining in this region. Not only the RE share is off-track, but the progress is also on a reverse trend. Unless immediate actions are taken, otherwise the share of RE in total final energy consumption by 2030 will be lower than it was in 2015. In order to achieve the SDG7 targets, efforts on deploying the RE share and reliance on clean energy will need to be accelerated by more than $80 \%$ and $20 \%$ respectively. On the other hand, none of the SDG13 indicators are on-track, moreover the resilience and adaptive capacity in this region is also on a reverse trend. Furthermore, $\mathrm{CO} 2$ emissions from fuel combustion will need to be further reduced by nearly $70 \%$ to achieve the 2030 target. Therefore, accelerating the energy transition through the ASEAN energy policy framework is the key in achieving the SDGs 7 and 13 


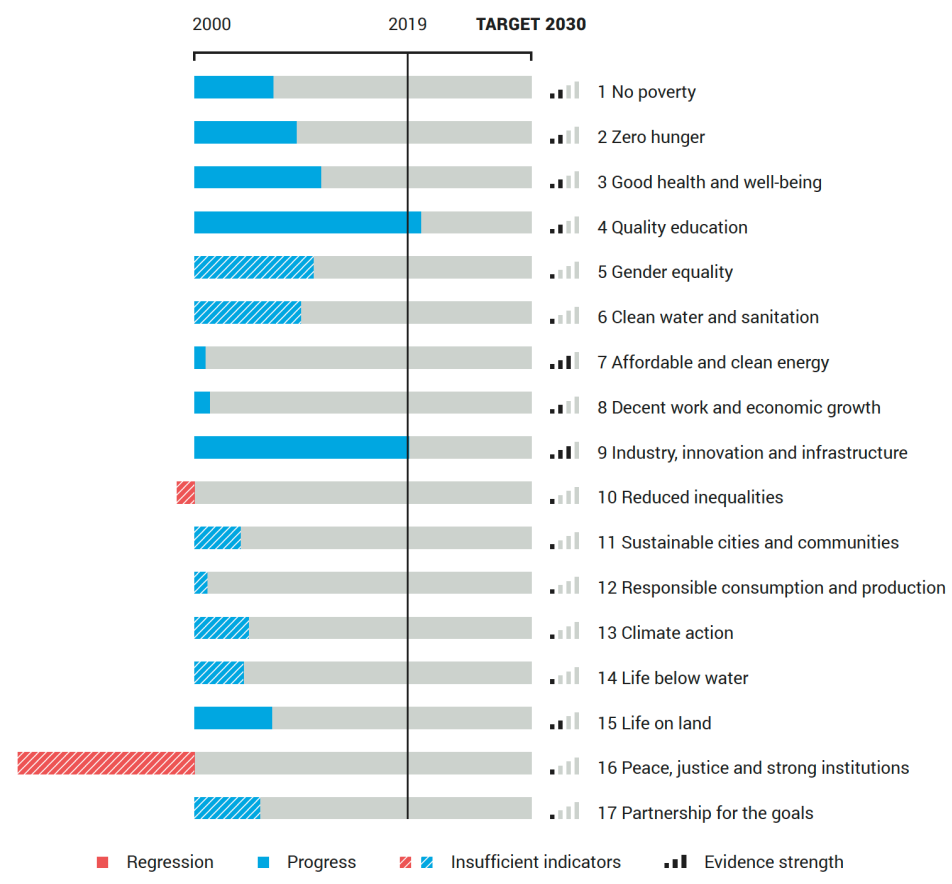

Figure 1 Southeast Asia SDG progress in 2019 [6]

\section{Progress and achievements of EE \& RE in the Southeast Asia}

While each of ASEAN Member States (AMS) has its own national energy target, the regional cooperation also has agreed to pursue an aspirational target of renewable energy (RE) and energy efficiency (EE). ASEAN is aiming to reach $23 \%$ of RE in the total primary energy supply (TPES), however, at the current progress, the share is still around $14.3 \%$ (Figure 2)[7]. With the five-year remaining, ASEAN has a lot opportunity to accelerate the effort. Looking into the detail statistic, half of the current RE share is contributed by the electricity sector. In order to achieve the target, it is foreseen that $42 \%$ of ASEAN generation needs to be from renewables which is approximately $165 \mathrm{GW}$ RE installed in total [5] .

Moreover, ASEAN needs to boost the effort in putting higher injection of RE in transport sector and heat. Biofuel will play more and more roles in increasing the RE share, noting that several ASEAN countries such as Indonesia and Thailand have ambitious target in using higher blend of biofuels for their transport fuels. To encourage more massive RE injection in ASEAN power sector, stronger regional connectivity has a significant role, as it is one of pathways to address resource mismatch based on geographic and temporal variation as it will enable clean energy sharing among ASEAN Member States and neighbouring countries [8]. 


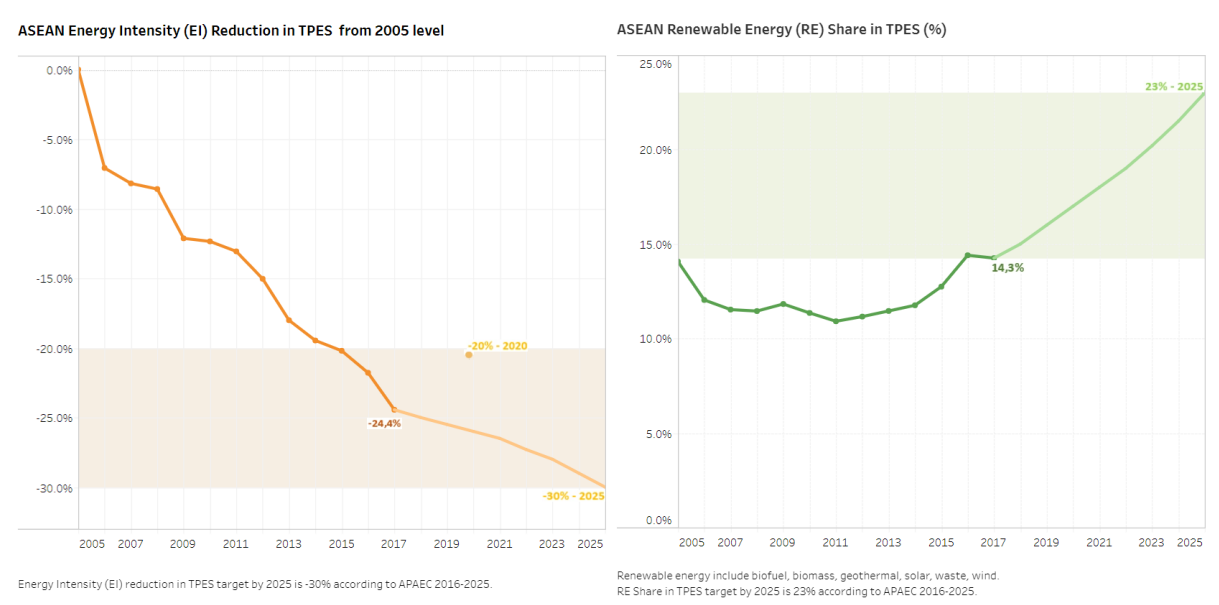

Figure 2 ASEAN APAEC target progress: RE share and EI reduction [7]

In energy efficiency, ASEAN is committed to reach $30 \%$ energy intensity (EI) reduction in 2025 by 2005 levels. At the moment, ASEAN is well-on-track so far to achieve the target as the energy intensity has been reduced by $24.4 \%$ in 2017 as seen in Figure 2 above [7]. In addition, some AMS have established plans to promote EE, calling for energy saving targets and the implementation of EE\&C measures [5]. However, to be able to track which EE efforts and policies are effective and which one to be improved, more define target and measurement of energy intensity in sectoral basis is required. Hence, the region could come up with more accurate and efficient effort in further reducing the energy intensity.

\section{ASEAN Low-carbon power generation: status and plans}

ASEAN electricity sector is still dominated by fossil fuels, mainly gas and coal (Figure 3). According to [9], ASEAN will foresee a growing role of coal and RE in the future. Under the scenario where ASEAN countries achieve their national target, coal-fired power plants are projected to grow from $63 \mathrm{GW}$ in 2015 to $95 \mathrm{GW}$ in 2025, and to $196 \mathrm{GW}$ in 2040. While natural gas comprises the largest installed capacity in 2015 with a share of $37.3 \%$, coal power plants are projected to surpass the installed capacity of natural gas in 2025 . It is very likely that the region will still be dependent on coal in the near future, considering the abundance of its reserve in several AMS.
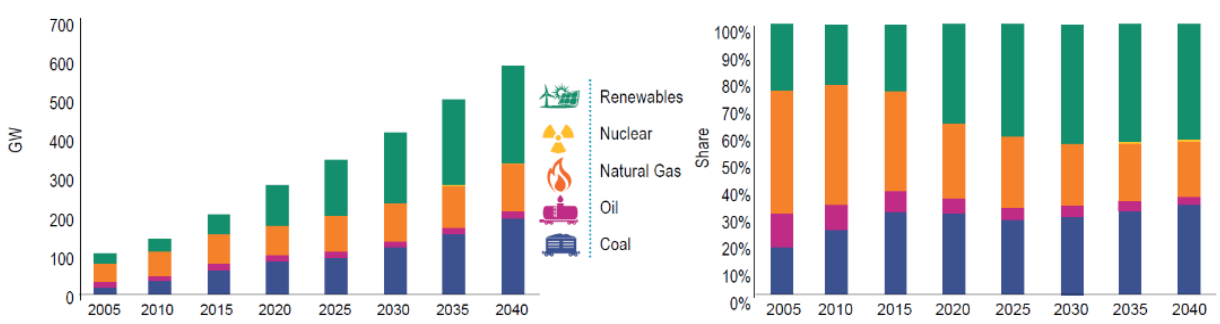

Figure 3 Projection of ASEAN installed capacity under ASEAN Target Scenario [5]

Following the AMS RE target, RE share will grow significantly in the power mix (Figure 4). There will be a shift in power generation from the formerly dominant natural gas to coal and $\mathrm{RE}$, where RE will become the largest power source in 2025 . At the moment, the most 
dominating RE in the power mix are geothermal and hydropower. While hydropower will still dominate in the future, variable RE utilization is also increasing significantly, especially solar. Global declining RE cost as well as supportive policies and incentive are the main enabler of higher RE utilization in the region. AMS with leading variable RE installation like Vietnam, Thailand, Malaysia and Philippines, has been implementing feed-in-tariff policies and other fiscal incentive to create the RE market in the country.
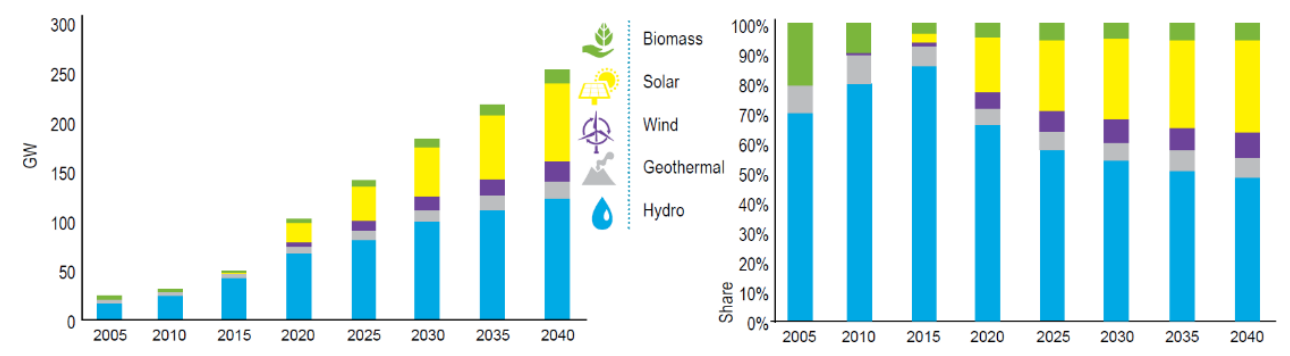

Figure 4 Projection of ASEAN RE installed capacity under ASEAN Target Scenario [5]

\section{Energy transition pathway to low-carbon society: Indonesia}

\subsection{Status, Plans, and Implementations on Policy Level}

Indonesia boast for its ambitious target for establishing low-carbon power generation. This can be indicated by their National Energy Policy to endorse the national energy policy to promote renewable energy share target of $23 \%$ by 2025 , along with its and energy elasticity target of $<1$ [9]. The projection of the renewable energy shares is even expected to reach up to $31 \%$ by 2050 . This is referred to the Indonesia's Presidential Decree No.22 Year 2017 concerning the National Energy General Plan [10]. It seems Indonesia's PDP was made aligned with the target, considering previous PDP, the Electric Power Supply Plan year 2017 - 2026: Electric Power Supply Plan developed by state-owned electricity company (PLN) features plan for renewable energy share in power mix target of $22.4 \%$ in 2026 . With the renewable is pushed toward in the energy projection, more low-carbon power generation are expected to be taken place in the future. As expressed in National Energy Policy (Kebijakan Energy Nasional/ KEN) Presidential Regulation No. 79 Year 2014 [9], Indonesia aimed its target of Primary Energy Supply on year 2025 for 400 MTOE, whereas on year 2050 for 1,000 MTOE. The target for Final Energy Consumption on year 2025 are expected by 1.4 TOE, whereas on year 2050 is $3.2 \mathrm{TOE}$. In regard to the power generation capacity, Indonesia aimed to reach $115 \mathrm{GW}$ by the year 2025, and $430 \mathrm{GW}$ by year 2050 . 
Table 1 Indonesia's regulatory framework compared to other ASEAN countries (2020) [11]

\begin{tabular}{|c|c|c|c|c|c|c|c|c|c|c|c|}
\hline \multicolumn{2}{|c|}{ Type of policy } & 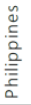 & 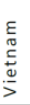 & 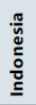 & 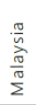 & 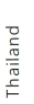 & 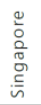 & 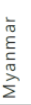 & 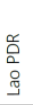 & 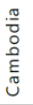 & 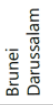 \\
\hline \multirow{8}{*}{ 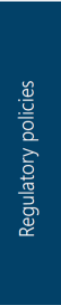 } & Renewable energy in INDC or NDC & $\bullet$ & $\bullet$ & $\bullet$ & $\bullet$ & $\bullet$ & $\bullet$ & $\bullet$ & $\bullet$ & $\bullet$ & $\bullet$ \\
\hline & Renewable energy targets & $\bullet$ & $\bullet$ & $\bullet$ & $\bullet$ & $\bullet$ & $\bullet$ & $\bullet$ & $\bullet$ & & $\bullet$ \\
\hline & Feed-in tariff/auctions/premium payment & $\bullet$ & $\bullet$ & $\bullet$ & $\bullet$ & $\bullet$ & & & & $\bullet$ & \\
\hline & Net metering/billing/direct consumption-supply & $\bullet$ & $\bullet$ & $\bullet$ & $\bullet$ & & $\bullet$ & & & & \\
\hline & Biofuel blend obligation/mandate/target & $\bullet$ & $\bullet$ & $\bullet$ & $\bullet$ & $\bullet$ & & & & & \\
\hline & Electric utility quota obligation/RPS & $\bullet$ & $\bullet$ & $\bullet$ & $\bullet$ & & & & & & \\
\hline & Tradable REC & & $\bullet$ & & & & & & & & \\
\hline & Renewable heat obligation/mandate & & & & & & & & & & \\
\hline \multirow{6}{*}{ 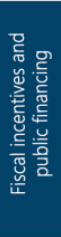 } & Tax incentives & $\bullet$ & $\bullet$ & $\bullet$ & $\bullet$ & $\bullet$ & & $\bullet$ & $\bullet$ & $\bullet$ & \\
\hline & Public investment/loans/grants/subsidies/rebates & $\bullet$ & $\bullet$ & $\bullet$ & $\bullet$ & $\bullet$ & $\bullet$ & & $\bullet$ & & \\
\hline & Reductions in sales, $\mathrm{CO}_{2}$ VAT or taxes & $\bullet$ & $\bullet$ & $\bullet$ & $\bullet$ & $\bullet$ & & $\bullet$ & & & \\
\hline & Tendering & $\bullet$ & & $\bullet$ & $\bullet$ & & $\bullet$ & & & & \\
\hline & Investment or production tax credits & $\bullet$ & $\bullet$ & $\bullet$ & & & & & & & \\
\hline & Energy production payment & $\bullet$ & & & & $\bullet$ & & & & & \\
\hline
\end{tabular}

The realisation of the pathway to low-carbon society has been seen exemplified in some pilot policy scheme. The Indonesia National Energy Council (DEN) aimed Target of energy elasticity $<1$ on year 2025, with adjustment according to economic growth. This realisation is also observed in the aim for action plan on reducing energy intensity $<1 \%$ per year until year 2025. DEN also marked their aim to reduce high-carbon power consumption, such as coal by $30 \%$ of the energy mix by 2025 and $25 \%$ by 2050 . DEN also forecast the oildependency reduction by $25 \%$ of the energy mix by 2025 and $20 \%$ by 2050 [11]. Further, the Indonesia Energy Plan (RUKN) [12] along with the utility PDP (RUPTL) [13] has been seen on track to establish agenda on prioritising the use of RE to improve National economy, while on the same time, optimise the use of national gas and new energy (hydrogen, coal bed methane, liquified coal, and gasified coal), and minimise the use of oil.

In regard to the establishment for the energy quality standard for domestics, MEMR also endorse Minimum Energy Performance Standards (SKEM) for Air Conditioning (AC) and Energy Saving Label [14]. This standard requires all domestic manufacturer and importer to apply SKEM and Energy Saving Level for AC in Indonesia's market. In addition, this regulation apply to AC with specification: single split wall mounted, cooling capacity of $27,000 \mathrm{BTU} /$ hour for inverter and non-inverter type. With such remarkable policy endorsements, Indonesia government committed to push strong support for low-carbon power utilisation as means to pathway low-carbon society in Indonesia.

Indonesia energy policy on RE covers wide range of regulation on energy as well as financial incentives, start from RE in NDC, RE target up to the utility quota obligation or RPS. While on the financial incentives the country implement tax incentives up to investment pr production tax credits. Those policy will increase 25\% the share of RE in 2030. However some challenges still lays ahead, when some of the policies is not being implemented well enough, for instance the involvement of banking system still remains low when the RE industry still categorizing with high risk investment. The government should take an action to take over the risk by providing warranty to the financial sectors.

\subsection{Practices and Implementations}

Some action plans on high level even are seen and compromised in practice level in order to streamline the target. According to Indonesia Ministry of Energy and Mineral Resources 
(MEMR), these action plans can be divided into building sector, energy sector, transportation sector, and industry sector $[15,16]$.

In the building sector, some action can be seen, such as increasing number of houses with piped natural gas connection. The city gas for household program based on RUEN will be expected to reach 4.7 million household connections by 2025 . To meet the target of city gas development in RUEN, there is a need to connect 1 million household connections per annum [11]. Further there is increased efficiency of household appliances and the implementation of mandatory energy management for energy-intensive users. For instance, In the last several years, the government has revoked energy subsidies such as subsidy for gasoline RON 88 (premium) and electricity for high income households [11], and the implementation of energy conservation partnership programme between MEMR and Asia Pacific Energy Research Centre (APERC) [17].

For energy sector, direct application can be seen in the conversion of Substitution of LPG to Induction Stove (2025: 0.5\%) and LPG substitution with DME (Dimethyl Ether) (2050: 20\%) [11]. Further, energy action plan to pave low-carbon and more efficient power generation can be indicated by the application of Presidential Instruction No. 13/2011 on Energy and Water Saving (Presidential Instruction No. 13 Year 2011), to push of biodiesel and biogas utilisation. Energy sector enhancement can be seen as well through some action in the development of the B30 biodiesel to cut costs, boost palm oil [18], and even Indonesia has started trial use of 40 percent biodiesel (B40) fuel in March 2020 [19].

On the transportation sector, some example can be observed on the utilisation of natural gas as fuel for urban public transports, such as in Jakarta. This action plan is also streamlined with the development of Intelligent Transport System, the reformation of transit, the construction of North South Mass Rapid Transport (MRT), the construction of SoekarnoHatta Airport railway track, and the construction of Jakarta Monorail. The action to path lowcarbon society in Indonesia can be seen even in the building of non-motorized transport lanes (pedestrian and bicycle lines).

In the industry sector, the action can be seen in some examples. Street Lighting Project under ADB Grant energy efficiency (Jakarta Local Government) for Rp. 2.4 Billion on 2016 with energy saving up to 73,6 MWh. The pilot for ISO 50001 Energy Management System of worth 10.3 Billion from 2015 to 2017 with potential energy saving up to $1409,5 \mathrm{GWh}$, whereas the project endowment were part-taken by UNIDO (United Nations Industrial Development Organization) [20].

\section{6 conclusion}

The 2030 Agenda for Sustainable Development, a shared blueprint for peace and prosperity was adopted by all United Nations Member States. The establishment of SDG7 together with SDG 13 on climate change mitigation from the energy sector endorse the ASEAN to submit a joint statement to the United Nations Climate Action Summit with key ASEAN targets for energy transition and transportation.

In order to achieve the key ASEAN targets for energy transition and transportation, efforts on deploying the RE share and reliance on clean energy will need to be accelerated by more than $80 \%$ and $20 \%$ respectively. Furthermore, $\mathrm{CO} 2$ emissions from fuel combustion will need to be further reduced by nearly $70 \%$ to achieve the 2030 target. Therefore, accelerating the energy transition through the ASEAN energy policy framework is the key in achieving the SDGs 7 and 13.

ASEAN is aiming to reach $23 \%$ of RE in the total primary energy supply (TPES). With the five-year remaining, ASEAN has a lot opportunity to accelerate the effort. Particularly for Indonesia, the country boasts for its ambitious target for establishing low-carbon power 
generation. This can be reflected by their Energy Development Plan to endorse national energy policy to promote renewable energy share target of $23 \%$ by 2025 .

The shaping of the renewables in low-carbon power utilisation has been reflected in the action plan in the transportation sector and manufacturing sector, such that it has been pushed to optimise effective and efficient power utilisation. As such, the alignment of low-carbon society in ASEAN has been in great progress considering its attempt to improve all power utilisation lineage.

\section{References}

1 ACE: 'Asean Plan of Action for Energy Cooperation' (2009), pp. 2004-2009

2 The ASEAN Secretariat: 'ASEAN Joint Statement to the United Nations Climate Action Summit 2019' (2019)

3 MOD: 'Brunei Darussalam's Intended Nationally Determined Contribution'

4 Lao PDR: 'Intended Nationally Determined Contribution (INDC), Lao People's Democratic Republic'

5 United Nations: 'Asia and the Pacific SDG Progress Report 2020 United' (2020)

6 'Energy interconnection in ASEAN for sustainable and resilient societies' (ASEAN Centre for Energy (ACE), GEIDCO, United Nation ESCAP, 2018)

7 'APAEC Target - ASEAN Energy Database System (AEDS)', https://aeds.aseanenergy.org/statistic/apaec-target/, accessed June 2020

8 'The 5th ASEAN Energy Outlook (AEO5)' (ASEAN Centre for Energy (ACE), 2017)

9 'Government Regulation of The Republic Of Indonesia Number 79 Of 2014 On National Energy Policy', http://ditjenpp.kemenkumham.go.id/arsip/terjemahan/2.pdf, accessed June 2020

10 'Regulation of The Minister Of Energy And Mineral Resources of The Republic of Indonesia number 50 Of 2017on Utilization of Renewable Energy Sources for Power Supply', http://ditjenpp.kemenkumham.go.id/arsip/terjemahan/41.pdf, accessed June 2020

11 'Indonesia Energy Outlook (IEO) 2019' (Secretariat General of the National Energy Council, 2019)

12 'RENCANA UMUM KETENAGALISTRIKAN NASIONAL 2019 - 2038', https://jdih.esdm.go.id/storage/document/Kepmen-esdm-143Thn\%202019\%20RUKN\%202019.pdf, accessed June 2020

13 'Rencana Usaha Penyediaan Tenaga Listrik PT. PLN (Persero)2019 - 2028', https:/gatrik.esdm.go.id//assets/uploads/download_index/files/5b16d-kepmen-esdm-no.-39-k20-mem-2019-tentang-pengesahan-ruptl-pt-pln-2019-2028.pdf, accessed June 2020

14 'Pemerintah Terapkan SKEM dan Pencantuman Label Hemat Energi Untuk Peranti Pengkondisi Udara - Kementerian ESDM Republik Indonesia', http://ebtke.esdm.go.id/post/2018/08/20/1997/pemerintah.terapkan.skem.dan.pencantuman.label. hemat.energi.untuk.peranti.pengkondisi.udara, accessed June 2020

15 MINISTRY OF NATIONAL DEVELOPMENT PLANNING: 'Guideline for Implementing Green House Gas Emission Reduction Action Plan', http://ranradgrk.bappenas.go.id/rangrk/admincms/downloads/publications/Gudeline_for_implem enting_green_house_gas_emission_reduction_action_plan.pdf, accessed June 2020

16 Ministry of Energy and Mineral Resources Republic of Indonesia: 'LOW CARBON DEVELOPMENT ON ENERGY SECTOR', http://www.iesr.or.id/wpcontent/uploads/2019/04/Rida-Mulyana.pdf, accessed June 2020

17 'APEC Energy Demand and Supply Outlook | 7th Edition | Vol. II'no date, p. 480.

18 'Indonesia launches B30 biodiesel to cut costs, boost palm oil'Reuters, 2019.

19 Post, T.J.: 'Indonesia to start trial use of 40 percent biodiesel (B40) fuel in March: Association'The Jakarta Post, no date.

20 Nurcahyanto, Simsek, Y., Urmee, T.: 'Opportunities and challenges of energy service companies to promote energy efficiency programs in Indonesia'Energy, 2020, 205, p. 117603. 